Tetiana Borysova,

D.Sc., Professor, West Ukrainian National University, Ukraine

ORCID ID, 0000-0003-2906-2769,

email: borisova.tanushka@gmail.com

Grygorii Monastyrskyi,

D.Sc., Professor, West Ukrainian National University, Ukraine

(D) ORCID ID, 0000-0001-6694-1960,

email: grymon@ukr.net

Olena Borysiak,

Ph.D., West Ukrainian National University, Ukraine

ORCID ID, 0000-0003-4818-8068,

email: olena.borysiak@gmail.com

Yuliia Protsyshyn,

Ph.D., West Ukrainian National University, Ukraine

ORCID ID, 0000-0002-9454-8602,

email: melenchykyuliia@gmail.com

Correspondence author: borisova.tanushka@gmail.com

\title{
PRIORITIES OF MARKETING, COMPETITIVENESS, AND INNOVATIVE DEVELOPMENT OF TRANSPORT SERVICE PROVIDERS UNDER SUSTAINABLE URBAN DEVELOPMENT
}

Abstract. Monitoring the growing role of implementing sustainable development goals, on the one hand, and the use of the Internet of things in various spheres of life, on the other, is changing the way people think about their mobility. The urgency of this scientific problem is the need to review municipal policies on approaches to the use of appropriate methods of public transport to improve municipal transport infrastructure policies in the light of advances in "green» energy development. This article justifies the need to focus on the study of changes in the Ukrainian taxi drivers' behavior in the urban environment on the development of "green» energy, development of appropriate programs to coordinate the requests of users and providers of taxi services through sustainable development and digitization of taxi services. In addition, the impact of sustainable energy development on transport diversification and the use of environmental modes of transport, in particular, electric cars as taxis, are analyzed, depending on the number of charging stations and access to electricity. The methodological tools used were cluster analysis, expert surveys, face-to-face interviews, statistical and fuzzy multiple estimation methods. The subject of the study was selected taxi services and taxi users in the Ternopil region. According to the survey results, the priority factors for the environmental behavior of Ukrainian taxi drivers were the level of business automation and the size of the taxi fleet. In a survey conducted by experts to examine the environmental safety of vehicles and the level of automation of enterprises, most taxi services were found to be environmentally unsound, focusing on sustainable development and environmental issues. The most problematic are technical support, automated ordering system, and significant vehicle wear in small cities. To determine the approaches to the management of greening, the objects of study were organized into relatively homogeneous groups. To this end, a cluster analysis was conducted. The study subjects were grouped into relatively homogeneous groups. The authors justified the feasibility of differentiated strategies and reaffirmed the idea of developing different approaches to environmental development depending on the level of environmental

Cite as: Borysova, T., Monastyrskyi, G., Borysiak, O., \& Protsyshyn, Yu. (2021). Priorities of Marketing, Competitiveness, and Innovative Development of Transport Service Providers under Sustainable Urban Development. Marketing and Management of Innovations, 3, 78-89. http://doi.org/10.21272/mmi.2021.3$\underline{07}$

78 
T., Borysova, G., Monastyrskyi, O., Borysiak, Yu., Protsyshyn. Priorities of Marketing, Competitiveness, and Innovative Development of Transport Service Providers under Sustainable Urban Development

friendliness of vehicles, business automation, and relative shares of the fleet. The study results could be useful for infrastructure scientists and practitioners, taxi managers and owners, and local government officials.

Keywords: autonomous taxi service, cluster analysis, electric cars, marketing, energy service companies, competitiveness, innovative development, municipal ecology, renewable energy sources, shared mobility, sustainable development.

Introduction. Monitoring climate change leads to intensifying human activities in identifying and eliminating factors related to these changes. Dynamic urban development leads to increased mobility which necessitates building convenient and environmentally friendly transport infrastructures. Demand for public transport can reduce carbon dioxide emissions from urban transport and prevent climate change. One of the most comfortable types of public transport is a taxi.

Given this, it is urgent to decrease taxi services' environmental impact on cities by switching from fossil-fuel-burning taxis to electric ones. It indicates the need for revising municipal policies regarding appropriate modes of public transport. «Green» energy trends (namely, accessibility to electric charging stations) can improve municipal transport infrastructures. In terms of these issues, it is pivotal to study several indicators as follows: the level of environmental safety of taxis; the level of automation and promotion on the Internet (website, social networks) of taxi services; and the share of electric vehicles in the taxi fleet, which directly shapes the demand for taxis in Ukraine as a transport means; and establish the environmental profile of taxi service providers.

Literature Review. One of the European Green Deal priorities (European Commission, 2019) in reducing harmful effects on the environment is the ecological diversification of transport based on renewable energy sources (solar energy, wind energy, hydropower, nuclear energy bioenergy, etc.). In particular, the concept of «green» energy transition within Ukraine to be completed by 2050 provides for the development of green transport in Ukraine. When evaluating the environmental profiles of taxi service providers, it is essential to note the study results (Hao et al., 2020). According to them, electricity consumption, traffic patterns, and battery charging (BEV) (fully electric driving mode) are significantly different from the type of car and the season. For example, BEV models with a range of $160 \mathrm{~km}$, which are charged on average every 1.6 days, can meet most personal transportation needs. The results also show that the actual power consumption of the BEV differs significantly from the consumption predicted by the New European Driving Cycle (NEDC) test, with the EC exceeding the projected NEDC test cycle by $7-10 \%$. Besides, the real range of $B E V$ for personal use in winter is only $64 \%$ out of the forecast level of NEDC. The study showed that when the ambient temperature is below $10^{\circ} \mathrm{C}$, electricity consumption increases by $2.4 \mathrm{kWh} / 100 \mathrm{~km}$ for every $5^{\circ} \mathrm{C}$ decrease in temperature. When it exceeds $28^{\circ} \mathrm{C}$, the EC increases by $2.3 \mathrm{kWh} / 100 \mathrm{~km}$ for every $5^{\circ} \mathrm{C}$ of temperature increase. From these findings, manufacturers need to design a BEV with an appropriate driving range and invest in R\&D to improve battery performance in cold conditions (Hao et al., 2020).

Accordingly, to ensure the approval of the environmental profile of transport service providers, marketing tools for the promotion of electric taxi services should be improved by considering the trends of digitalization of business processes and promotion of sustainable joint mobility. In particular, (Kim et al., 2020) proposed the Autonomous Taxi Service (Autonomous Taxi Service Design) design, which includes recommendations for creating and verifying autonomous taxi services. If the technology of self-driving is imperfect, it can be supplemented by using service flexibility. It is essential to determine the impact of using mobile applications for ordering a taxi on the financial condition and activities of the entire industry: the constant decline in service prices, which pushes competitors out of the market of taxi services; reducing the quality of service in companies that provide taxi services through mobile applications; income reduction in companies providing taxi services through traditional channels (Akbulaev, 2020). Besides, (Sho et al., 2020) offered a platform for taxi drivers, which automatically searches for customers and optimizes the ordering route depending on traffic jams and environmental pollution. 
T., Borysova, G., Monastyrskyi, O., Borysiak, Yu., Protsyshyn. Priorities of Marketing, Competitiveness, and Innovative Development of Transport Service Providers under Sustainable Urban Development

Following the Sustainable Development Goals, improving forecasting traffic flows in urban space and time is essential (e.g., models of daily flow activity, flow patterns, weather effects, weekends, and holidays). According to Xie et al. (2020), it requires up-to-date information on traffic flow from different sources in different areas, such as mobile phone data, taxi trajectory data, metro/bus travel data, bicycle exchange data. At the same time, following the principles of urban ecology, the level of transport diversification is increasing through using environmentally friendly modes of transport as a contribution to improving the sustainable development of urban mobility (Deschenes et al., 2020; Nguyen-Phuoc et al., 2020; Lokhandwala and Hua, 2020; Liakhovych et al., 2021; Welch et al., 2020; Brych et al., 2021). Welch et al. (2020) showed that the travel cost and natural factors, land diversity, and connectivity indicators affect the choice of transport mode (taxi or bicycle, rather than rail). Besides, bicycle services are becoming popular worldwide, which has led to the study of factors influencing the customers' loyalty to bike-taxi services, for example (Nguyen-Phuoc et al., 2020). The results obtained in this paper showed that passenger satisfaction and loyalty depend on three factors: the intended benefits of the booking, sales promotion, and quality of service program, where the last one dominates other factors.

Another popular form of environmentally friendly transport is electric cars. They are cheap to refuel. Besides, they provide a competitive advantage for taxi services. Deschenes et al. (2020) proposed a hybrid physical-empirical model for predicting the level of taxi electricity consumption from one point to another. Besides, it is urgent to optimize the location of charging stations for joint autonomous fleets (Lokhandwala and Cai, 2020; Zhuang et al., 2020; Guo et al., 2020). Guo et al. (2020) proposed combining charging stations and battery exchange stations (BES) to solve the infrastructure problem for electric taxis. Lokhandwala and Cai (2020) propose a framework to optimize charging infrastructure development for increasing electric vehicle (EV) adoption in systems with different autonomous vehicle adoption and ridesharing participation levels. The model also considers the existing charging infrastructure, the alternation of cars at charging stations, trade-offs between the construction of new charging stations, and the expansion of existing ones with more charging ports (Lokhandwala and Cai, 2020). Environmentally friendly modes of transport change the management of urban taxi infrastructure through digital interaction with customers. It is pivotal to predict customers' behavior (Kieu et al., 2020), the problem of automatic taxi travel based on the congestion analysis (Liang et al., 2020).

This literature review testifies to the urgency of approving the environmental profile of taxi service providers in the context of sustainable development and climate change prevention. Given this, it is necessary to deepen the understanding of the behavior of environmental taxi users through the definition of environmental factors (indicators of efficiency of taxi service providers).

Methodology and research methods. There is an urgent need for the greening of transport, the introduction of autonomous urban transport infrastructure management systems, and, consequently, a change of attitude towards the use of taxis, considering the level of transport safety, reasonable specialization, and transport sharing. Besides, the transport sector is undergoing three revolutions: shared mobility, autonomous driving, and electrification. Planning the charging infrastructure for electric vehicles requires considering the potential interactions and synergies between these three new systems (Lokhandwala and Cai, 2020). Besides, it is necessary to focus on changes in taxi users' behavior in the municipal environment, «green» energy development, and appropriate programs to match the requests of users and taxi service providers based on sustainable development and digitalization of taxi services.

The study methodological tools were cluster analysis, expert surveys, face-to-face interviews, statistical and fuzzy multiple estimation methods. According to the logic of fuzzy sets [2], verbal statements of experts can acquire such meanings as true, false, absolutely false, absolutely true, not entirely true, not entirely false, etc. These values represent a fuzzy subset of a unit interval $[0,1]$. Fuzzy models are the most appropriate for assessing the quality of services of research objects, as accurate and stochastic models require accurate but distributed information for the second case, which is usually not provided. 
T., Borysova, G., Monastyrskyi, O., Borysiak, Yu., Protsyshyn. Priorities of Marketing, Competitiveness, and Innovative Development of Transport Service Providers under Sustainable Urban Development

Since fuzzy set theory describes concepts and knowledge that are difficult for conventional mathematical methods, expert systems based on fuzzy set theory have significant advantages over expert systems with two-valued logic. First, operation on input data that are vaguely defined is highly likely. These are values that cannot be specified unambiguously. Second, evaluation and comparison criteria can be fuzzily formalized with the concepts «more», «possible», «mostly», etc. Third, qualitative assessments of both input data and output results can be applied. It is proposed to use fuzzy expert systems in urban public transport, specifically to assess the quality of taxi services. It deverbalizes the linguistic variables obtained during the peer review into more conveniently comparable assessments of the service quality level. The purpose of this study is to find a rational model for building a knowledge base of an expert system for assessing the quality of taxi services. The apparatus of fuzzy sets and deverbalization of linguistic variables and cluster analysis would be used. Marketing and innovation priorities of business entities would be justified using the abovementioned apparatus.

Results. The European Commission implements programs to strengthen partnerships between the EU Member States and their neighbors in combating climate change. It allows supporting measures to prevent climate change through green energy and environmentally friendly modes of transport: EU4Energy (2016-2020), EU4Climate (2018-2022), EU4Digital (European Union, 2020a, 2020b). In Ukraine, the implementation of European experience and support for European cross-border cooperation initiatives is carried out by implementing the principles of municipal ecology, smart city, and environmentally friendly modes of transport. Adopted in December 2019, the European Green Deal (European Commission, 2019) is the foundation for developing a climate-neutral economy, renewable energy, and environmentally friendly and smart transport (electric vehicles) until 2050. Accordingly, it is essential to create an extensive infrastructure to develop electric transport in Ukraine.

For 2014-2018, the primary energy sources for transport in Ukraine (ranked by consumption) were: 1) petroleum products; 2) natural gas; 3) electricity; 4) biofuels and waste; 5) coal and peat (State Statistics Service of Ukraine, 2019; Borysova and Monastyrskyi, 2018). Despite the diversification of renewable energy sources, Ukraine witnessed a positive trend in reducing the transport consumption of electricity compared to the previous year. The analysis shows the urgency of developing measures to promote environmentally friendly modes of transport through sustainable transport infrastructure (installation of charging power plants), especially in cities. That can be achieved through the establishment of communication between energy service companies and local governments.

At the same time, positive dynamics are observed among electric car users in Ukraine. According to the Association of Manufacturers of Ukraine «Ukravtoprom», during January-September 2019, 5081 electric cars and 397 commercial electric cars in Ukraine, which is twice as many as in 2018 (UkrAvtoprom, 2018; Brych et al., 2020). The number of charging stations for electric vehicles in Ukraine increased from 600 in 2016 to 1,000 in 2018 (TSNUA, 2018). It indicates the development of sustainable thinking and the formation of the environmental behavior of transport users.

Electrification of vehicles can help reduce environmental pollution. However, rapid electricity consumption and inconvenient recharging services limit the widespread introduction of electric vehicles, especially in the taxi industry. It necessitates improving the infrastructure for powering batteries for electric taxis (Guo et al., 2020). It is therefore essential to determine the optimal range of battery-operated electric vehicles (including taxis) from batteries (BEV) (fully electric driving range). Zhou et al. (2020) proposed a model for determining the minimum range of BEV batteries that can meet specific road requirements, considering the charging capacity of existing public stations and uncertainty in making charging decisions. As for taxis, the BEV with a battery range of 220 miles can meet the travel needs of about $90 \%$ of drivers. Private vehicles require a distance of 300 miles to cover the needs of $90 \%$ of drivers, while a battery of 100 miles can meet the needs of $80 \%$ of private drivers (Zhou et al., 2020). 
T., Borysova, G., Monastyrskyi, O., Borysiak, Yu., Protsyshyn. Priorities of Marketing, Competitiveness, and Innovative Development of Transport Service Providers under Sustainable Urban Development

Given this, it is advisable to consider the charging behavior model of electric vehicles drivers, proposed by Van Der Kam et al. (2019). This model consists of electric vehicles drivers, charging stations, renewable energy, and the built environment. In this scientific work, three models are considered under the behavior of drivers of electric vehicles: 1) electric vehicles are always charged at maximum power (until full battery charge); 2) electric cars are always charged with maximum power until the battery level is at a certain minimum level selected by the agent); 3) electric cars are charged in case of available additional opportunities to obtain renewable energy. The model simulates two versions of this system, which have central control over charging points and one that does not have central control. Agents have maximum power for excess renewables (Van Der Kam et al., 2019). Such research results lead to developing a unified communication channel between energy service companies, gas stations, and electric vehicles users based on digitalization and smart specialization of transport infrastructure. There is a positive trend in the number of users of electric vehicles and an increase in energy production from renewable sources. It actualizes the deepening of the study of marketing tools for the promotion of electric taxi services by considering the trends of digitalization of business processes and the promotion of sustainable joint mobility. The main stages of marketing social networks to promote taxi services are community building, content creation, attracting users, and community management. Webpages of taxi services contribute to the growth of demand for services because customers can get all the necessary information, namely: the current tariffs; download the mobile application; calculate the cost; order a taxi immediately or for a particular time; choose the taxi class; find out if smoking and animals transportation; customer reviews; current vacancies, etc. (0352.ua, 2020; Borysova et al., 2019).

60 respondents - residents of Ternopil and Ternopilska Oblast took part in the marketing research conducted in January-March 2020 using personal interviews (Zielinska and Borysova, 2020). According to the results of expert assessment, the weighting factors of the level of the environmental profile of vehicles can be represented as follows:

$$
l_{e}=0.6 * l_{\text {res }}+0.2 * l_{\text {man }}+0.1 * l_{S C}+0.1 * l_{\text {id }}
$$

Thus, the experts attached the most significant importance to the resource and management components of the environmental profile of vehicles -0.6 and 0.2 , respectively. A slightly lower weighting factor is assigned to the scientific, methodological, and ideological components of environmental vehicles friendliness -0.1 each. Expert surveys on the quality of taxi services were conducted in three stages using the Delphi Method. After the first stage, the level of agreement of experts on the concordance coefficient was 0.340622 , after the second stage 0.472445 , and after the third stage, it was 0.7254974 . Because the coefficient for the third evaluation stage was high (Table 1), generalized analysis of the survey results from this stage was conducted, as experts' opinions in the fourth stage were not consistent.

The sum of the ranks of each indicator $S_{j}$ is determined by the formula (2):

$$
S_{j}=\sum_{i=1}^{m} R_{i j}
$$

where $R_{\mathrm{ij}}$ is the rank of the $i$-th expert of the $j$-th indicator; $m$ - the number of experts who evaluated the $j$-th indicator.

The average values of the ranks of each $\bar{S}_{\text {j }}$ indicator are determined by the formula (3):

$$
\bar{S}_{j}=\frac{\sum_{i=1}^{m} R_{i j}}{m}=\frac{S_{j}}{m}
$$

The values obtained during the third stage of the survey were ranked (Table 1), the ranks were 
T., Borysova, G., Monastyrskyi, O., Borysiak, Yu., Protsyshyn. Priorities of Marketing, Competitiveness, and Innovative Development of Transport Service Providers under Sustainable Urban Development

grouped. Standardized ranks were identified, and the concordance coefficient was calculated.

Table 1. Ranking results

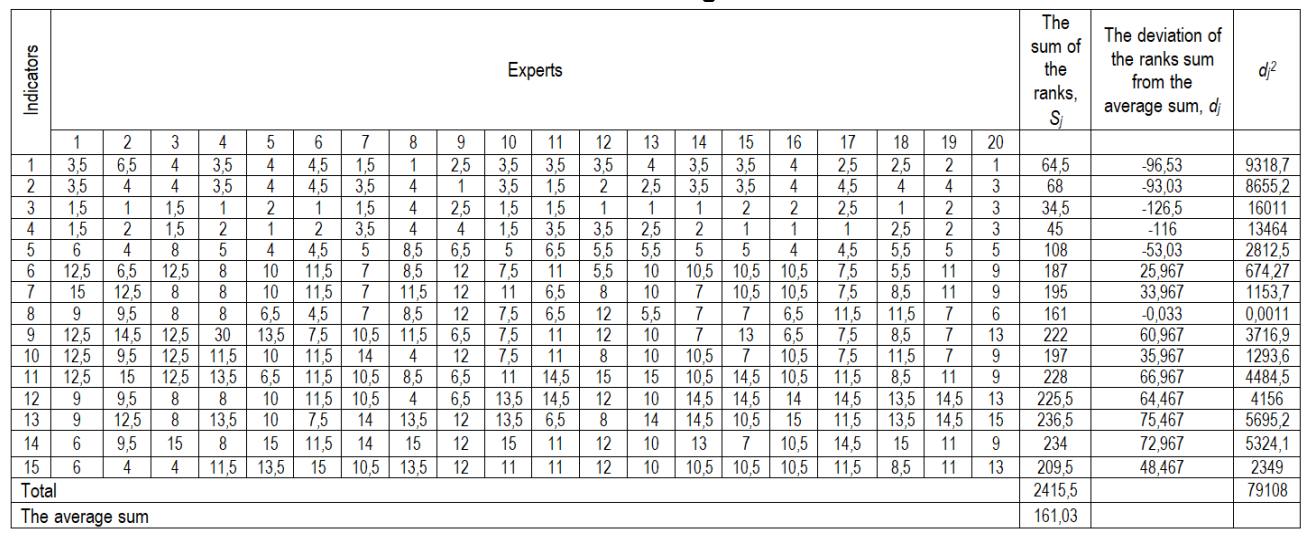

Sources: developed by the authors.

In this case, the ranks were standardized, so the concordance coefficient $K_{\text {con }}$ was calculated by formulas (4), (5), (6):

$K_{c o n}=\frac{12 \sum_{j=1}^{n} d_{j}^{2}}{m^{2}\left(n^{3}-n\right)-m \sum_{i=1}^{m} T_{i}}$

$T_{i}=\sum_{l=1}^{L}\left(t_{l}^{3}-t_{l}\right)$

where $I$ is the number of groups of related ranks; $t_{i}$ is the number of related ranks in each group.

$d_{j}=S_{j}-\frac{\sum_{j=1}^{n} S_{j}}{n}$

where $d_{j}$ is the deviation of the sum of the rank from the average sum; $S_{j}$ - the sum of the ranks of the $j$-th indicator; $n$ is the number of evaluated factors; $m$ - the number of experts.

The data of expert evaluation have led to the following values of $T_{i}$ indicators:
$\mathrm{T}_{1,5}=\left(2^{3}-2\right)=6$;
$\mathrm{T}_{2}=\left(3^{3}-3\right)=24$;
$\mathrm{T}_{8}=\left(5^{3}-5\right)=120$
$\mathrm{T}_{2,5}=\left(2^{3}-2\right)=6$;
$\mathrm{T}_{8,5}=(43-4)=60$;
$\mathrm{T}_{3}=\left(3^{3}-3\right)=24$;
$T_{9}=\left(5^{3}-5\right)=120$;
$T_{3,5}=\left(2^{3}-2\right)=6$;
$\mathrm{T}_{9,5}=(43-4)=60$
$\mathrm{T}_{4}=\left(5^{3}-5\right)=120$;
$\mathrm{T}_{10,5}=\left(6^{3}-6\right)=210$;
$\mathrm{T}_{4,5}=(43-4)=60$;
$\mathrm{T}_{11,5}=\left(6^{3}-6\right)=210$;
$\mathrm{T}_{5,5}=\left(2^{3}-2\right)=6$;
$\mathrm{T}_{12}=(73-7)=336$;
$\mathrm{T}_{6}=\left(3^{3}-3\right)=24$;
$\mathrm{T}_{12,5}=(43-4)=60$;
$\mathrm{T}_{6,5}=(43-4)=60$;
$\mathrm{T}_{13,5}=\left(2^{3}-2\right)=6$;
$\mathrm{T}_{7}=(33-3)=24$;
$\mathrm{T}_{13}=\left(3^{3}-3\right)=24$;
$\mathrm{T}_{7,5}=(43-4)=60$;
$\mathrm{T}_{14}=\left(3^{3}-3\right)=24$;
$\mathrm{T}_{14,5}=\left(2^{3}-2\right)=6$.
$\mathrm{T}_{\mathrm{i}}=1776 ; \mathrm{d}_{\mathrm{j}}^{2}=79108 ; \mathrm{K}_{\mathrm{con}}=0,7254974$.

Thus, the obtained value of the concordance coefficient indicates sufficiently consistent experts' 
T., Borysova, G., Monastyrskyi, O., Borysiak, Yu., Protsyshyn. Priorities of Marketing, Competitiveness, and Innovative Development of Transport Service Providers under Sustainable Urban Development

opinions and reliability of their assessments for the importance of indicators.

Table 2 provides an assessment of vehicle environmental friendliness, the level of business automation, and the relative shares of the fleet, with some taxi services in Ternopil and four raions.

Table 2. Assessment of vehicle environmental friendliness, level of business automation, and relative proportion of taxi fleet surveyed in Ternopil and raions (district centers)

\begin{tabular}{|c|c|c|c|c|c|}
\hline $\begin{array}{c}\text { Taxi services } \\
\text { Ternopil and } \\
\text { district } \\
\text { centers of } \\
\text { Ternopilska } \\
\text { oblast }\end{array}$ & $\begin{array}{l}\text { Integrated } \\
\text { indicators of } \\
\text { the level of } \\
\text { business } \\
\text { automation }\end{array}$ & $\begin{array}{l}\text { Conclusions about } \\
\text { the level of } \\
\text { business } \\
\text { automation }\end{array}$ & $\begin{array}{c}\text { Integral } \\
\text { indicators of } \\
\text { the level of } \\
\text { environmenta } \\
\text { I friendliness } \\
\text { of vehicles }\end{array}$ & $\begin{array}{l}\text { Findings on the } \\
\text { level of } \\
\text { environmental } \\
\text { friendliness of } \\
\text { vehicles }\end{array}$ & $\begin{array}{l}\text { Relative } \\
\text { fleet } \\
\text { share }\end{array}$ \\
\hline Pilot & 0,72 & $\begin{array}{l}\text { by } 60 \% \text { high, } \\
\text { by } 40 \% \text { average }\end{array}$ & 0,48 & By $100 \%$ average & 0,8 \\
\hline Opti & 0,71 & $\begin{array}{l}\text { by } 55 \% \text { high, } \\
\text { by } 45 \% \text { average }\end{array}$ & 0,48 & By $100 \%$ average & 0,8 \\
\hline Premium & 0,48 & by $100 \%$ average & 0,28 & $\begin{array}{l}\text { By } 60 \% \text { low, } \\
\text { by } 40 \% \text { average }\end{array}$ & 0,5 \\
\hline $\begin{array}{l}917 \text { Nove taxi } \\
\text { (New taxi) }\end{array}$ & 0,48 & by $100 \%$ average & 0,29 & $\begin{array}{c}\text { By } 55 \% \text { low, } \\
\text { by } 45 \% \text { average }\end{array}$ & 0,5 \\
\hline 549 & 0,48 & By $100 \%$ average & 0,29 & $\begin{array}{c}\text { By } 45 \% \text { average, } \\
\text { by } 55 \% \text { low }\end{array}$ & 1 \\
\hline Joker 828 & 0,29 & $\begin{array}{l}\text { By } 55 \% \text { low, } \\
\text { by } 45 \% \text { average }\end{array}$ & 0,29 & $\begin{array}{l}\text { By } 55 \% \text { low, } \\
\text { by } 45 \% \text { average }\end{array}$ & 0,8 \\
\hline $\begin{array}{l}\text { Halych } \\
\text { (Zbarazh) }\end{array}$ & 0,28 & $\begin{array}{l}\text { By } 60 \% \text { low, } \\
\text { by } 40 \% \text { average }\end{array}$ & 0,27 & $\begin{array}{l}\text { By } 65 \% \text { low, } \\
\text { by } 35 \% \text { average }\end{array}$ & 0,2 \\
\hline $\begin{array}{l}\text { Cruise taxi } \\
\text { (Chortkiv) }\end{array}$ & 0,27 & $\begin{array}{c}\text { By } 65 \% \text { low } \\
\text { by } 35 \% \text { average }\end{array}$ & 0,27 & $\begin{array}{l}\text { By } 65 \% \text { low, } \\
\text { by } 35 \% \text { average }\end{array}$ & 0,3 \\
\hline $\begin{array}{l}\text { Siaivo } \\
\text { (Terebovlia) }\end{array}$ & 0,26 & $\begin{array}{c}\text { By } 70 \% \text { low, } \\
\text { by } 30 \% \text { average }\end{array}$ & 0,27 & $\begin{array}{l}\text { By } 65 \% \text { low, } \\
\text { by } 35 \% \text { average }\end{array}$ & 0,2 \\
\hline $\begin{array}{l}\text { Taxi plus } \\
\text { (Berezhany) }\end{array}$ & 0,26 & $\begin{array}{l}\text { By } 70 \% \text { low, } \\
\text { by } 30 \% \text { average }\end{array}$ & 0,26 & $\begin{array}{l}\text { By } 70 \% \text { low, by } \\
30 \% \text { average }\end{array}$ & 0,2 \\
\hline
\end{tabular}

Sources: developed by the authors based on their own research.

The study found that $20 \%$ of the surveyed taxi services have a highly integrated level of business automation, 30\% - medium, and 50\% - low level of this indicator. The research results showed that the studied taxi services resource, management, scientific and methodological, ideological opportunities to ensure the environmental safety of vehicles in their fleet are low. The fragment of the assessment of the integrated indicator of the level of the environmental profile of the vehicles of the taxi service « 917 Nove Taxi (New Taxi)» using fuzzy sets is given below. The general scheme of linguistic classification was as follows:

1. Expert assessment was performed using the scoring method (Granaturov and Shevchuk, 2000; Grabovetsky, 2010). An expert group to determine the weighting factors of the environmental profile of vehicles consisted of ten experts (marketing specialists). As a result of the expert survey questionnaires, a set of data was obtained on the level of partial indicators of the Integrated Environmental Performance Index of Vehicles.

2. All partial indicators of the environmental profile of vehicles were compared with 01-carrier. To recognize the level of these factors, a standard three-level 01-classification is used, which is graphically depicted in the figure, with the subsets «Low level», «Medium level», «High level» of the linguistic variable 
T., Borysova, G., Monastyrskyi, O., Borysiak, Yu., Protsyshyn. Priorities of Marketing, Competitiveness, and Innovative Development of Transport Service Providers under Sustainable Urban Development

«Factor level». Experts from taxi services determined the assessment of each indicator of environmental safety of vehicles.

3. Ten experts were surveyed to determine the weights of the factors.

4. Partial indicators of the environmental profile of vehicles are determined. The level of the environmental performance of vehicles was carried out based on expert survey data and using the formula given in (Nedosekin, 2004):

$l_{e}=\sum_{j=1}^{5} \sum_{i=1}^{n} p_{i} \times \mu_{i, j}$

where $p_{i}$ - weight factor; $j$-nodal point; $\mu$ - the value of the nodal point; $n$ - number of partial indicators.

Calculation of partial environmental performance of vehicles based on expert estimates:

4.1. Calculation of the level of the resource component of environmental friendliness of vehicles: Ires $=0,5$

4.2. Calculation of the level of scientific and methodological component of environmental friendliness of vehicles: Isc $=0,4$;

4.3. Calculation of the level of the management component of environmental friendliness of vehicles: Iman $=0,6$;

4.4. Calculation of the level of the ideological component of environmental friendliness of vehicles: Iid $=0,4$;

5. Determined integrated indicator of environmental friendliness of vehicles:

$$
\text { Ie }=0,6 \times 0,5+0,2 \times 0,4+0,1 \times 0,6+0,1 \times 0,4=0,48
$$

The membership function of the subset «High factor», defined on the 01-carrier $\mathrm{l}_{\mathrm{e}}$, has the following analytical form:

$$
\mu_{3}\left(I_{e}\right)=\left\{\begin{array}{c}
0,0 \leq I_{e}<0,6 \\
5\left(I_{e}-0,6\right) \leq I_{e}<0,8 \\
1,0,8 \leq I_{e} \leq 1
\end{array}\right.
$$

The membership function of the subset «Average factor level», defined on 01-carrier le, has the following analytical form:

$$
\mu_{2}\left(I_{e}\right)=\left\{\begin{array}{c}
0,0 \leq I_{e}<0,2 \\
5\left(I_{e}-0,2\right), 0,2 \leq I_{e}<0,4 \\
1,0,4 \leq I_{e}<0,6 \\
5\left(0,8-I_{e}\right), 0,6 \leq I_{e}<0,8 \\
0,0,8 \leq I_{e} \leq 1
\end{array}\right.
$$

Then:

$$
\mu_{1}\left(l_{e}\right)=1-\mu_{2}\left(l_{e}\right)-\mu_{3}\left(l_{e}\right)
$$

According to the abovementioned formulas, the acceptance of the indicator's value concludes that the composite environmental friendliness indicator for taxis, «917 Nove taxis (New taxi)» for 100 percent, is average. The cluster analysis allowed to group objects into homogeneous groups. The study included a 
T., Borysova, G., Monastyrskyi, O., Borysiak, Yu., Protsyshyn. Priorities of Marketing, Competitiveness, and Innovative Development of Transport Service Providers under Sustainable Urban Development

discussion of the results, highlighted experts' contribution to science, practice, and the problem that the results solve.

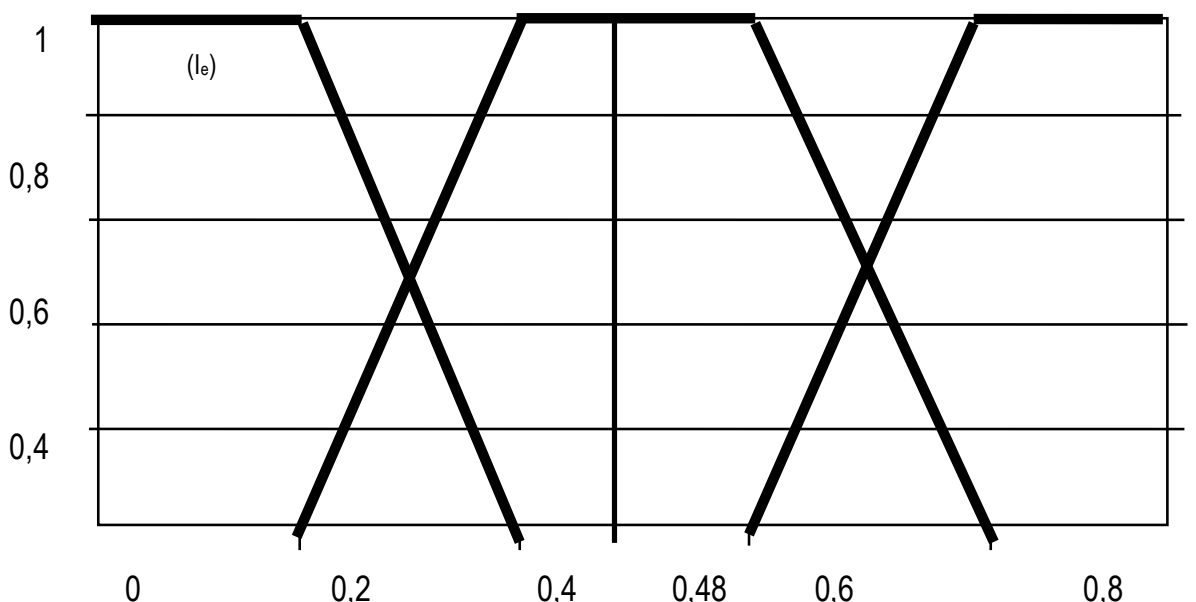

Figure 1. Three-level 01-classification of the level of the integrated indicator of environmental friendliness of vehicles of the taxi service «917 Nove taxi (New taxi)»

Sources: developed by the authors based on their own research

Automatization of business and the size of the taxi fleet affect environmental behaviors among Ukrainian taxi users. Expert surveys to study the environmental friendliness of vehicles and the level of business automation found that most of the surveyed taxi services have low eco-friendly transport, sustainable development, and fragmentary environmental friendliness. The most problematic issues are technical support, automated ordering systems, and vehicle wear in small towns. To determine management greening methods, the objects of the research into homogeneous groups were distributed. Clustering to group the relatively homogeneous research objects and justify the feasibility of differentiated strategies were used. The idea of developing different approaches to environmental development depending on the level of eco-friendliness of vehicles, business automation, and relative fleet shares was confirmed here. The main scientific results of the study are as follows:

1. A scientific and methodological approach to the strategy for innovative development of urban public transport to identify their strategic position and ways to strengthen the competitive position in the transport services market was developed.

2. The concept of integrating the marketing system of the public transport entity with the components of the marketing environment was formulated. It considers the environmental friendliness of vehicles, the level of business automation, and the relative size of taxi services in terms of the fleet to the biggest competitor on the local market.

3. Empirical research has established the current level of taxi services on the domestic market; we suggested recommendations for developing this marketing tool among subjects who participated in this study.

Survey results are not limited to only Ternopilska Oblast. Moreover, the sample representativeness and compliance with the expert survey procedure expand their usage to the national level. The obtained scientific results solve the problem of sufficient methodological recommendations for identifying areas of innovative development. The research offers an improved methodological approach based on the differentiation of public transport enterprises by service quality and fleet development. 
T., Borysova, G., Monastyrskyi, O., Borysiak, Yu., Protsyshyn. Priorities of Marketing, Competitiveness, and Innovative Development of Transport Service Providers under Sustainable Urban Development

Conclusions. Studying scientific and analytical works of foreign scientists necessitated the research on the behavior of Ukrainian taxi drivers in the urban environment, the development of «green» energy, and appropriate programs to coordinate the requests of users and providers of taxis based on sustainable development. The sources of energy for transport in Ukraine (ranked by consumption) for the last three years were: 1) petroleum products; 2) natural gas; 3) electricity; 4) biofuels and waste; 5) coal and peat. Despite the diversification of renewable energy sources, electricity consumption by transport in Ukraine has reduced compared to the previous year. The analysis shows that it is urgent to develop environmentally friendly transport modes with sustainable infrastructure (installation of charging stations), especially in cities. It is proved by linking energy companies with local authorities and communication between energy service companies and local governments.

The level of business automation and the size of the taxi fleet are crucial in the environmental behavior of Ukrainian taxi drivers. Experts surveyed to examine the level of environmental friendliness of vehicles. The level of automation of enterprises found that most taxi services surveyed have a low level of sustainability of their vehicles. Besides, the focus on sustainable development and environmental friendliness is insufficient. The most problematic issues are technical support, lack of automatic order systems, and a high amount of wear and tear vehicles in small towns. The research subjects were divided into relatively homogeneous groups to identify approaches to greening processes. Under the above, a cluster analysis grouped the study objects into relatively homogeneous groups; justified the differentiated strategies feasibilities; reaffirmed the idea of developing different approaches to environmental development depending on the level of environmental friendliness of vehicles, the automation of the business, and the relative share of the fleet. The results of the study are useful for practitioners because:

1. A scientific and methodological approach of indicators that reflects service quality and innovative development was developed. Public transport management would identify and strengthen the main marketing factors that most significantly influence social, environmental, and economic effects.

2. The methodical approach to the estimation of indicators of innovative development of researched subjects was improved. Thus, it would simplify the definition of the current and desirable strategic position and the competitors for the transportation management, considering the level of eco-friendliness of vehicles, business automation, and relative size of taxi services vehicles to the largest competitor in the local market. The transport industry managers will decide on their available and desirable strategic position and the competitors, considering the level of eco-friendliness of vehicles, level of automation of business, and relative size of taxi services vehicles to the largest competitor in the local market.

3. The methodological approach to grouping researched subjects to define approaches to innovative development of homogeneous groups is improved. Cluster analysis allowed substantiating the feasibility of developing differentiated approaches to enterprises with the different environmental friendliness of vehicles and business automation.

Therefore, the research can be useful for scientists and infrastructure practitioners, managers and owners of taxi services, and representatives of local municipal authorities. Further research prospects in this field are to study the development vectors of marketing and Internet communication policies of businesses that provide public transport services.

Author Contributions: conceptualization, T. B., Yu. P. and O. B.; methodology, T. B. and Yu. P.; software, T. B.; validation, T. B., G. M., and O. B.; formal analysis, O. B.; investigation, T. B. and Yu. P.; resources, T. B, O. B. and Yu. P.; data curation, G. M.; draft preparation, T. B.; review and editing, T. B., G. M., and O. B.; visualization, T. B. and O. B.; supervision, G. M.; project administration, T. B.

Funding: This research received external funding. The authors express their gratitude to the Ministry of Education and Science of Ukraine, with the support of which an article was published in the framework of the scientific work of young scientists on the topic: «Formation of the mechanism of sustainable urban 
T., Borysova, G., Monastyrskyi, O., Borysiak, Yu., Protsyshyn. Priorities of Marketing, Competitiveness, and Innovative Development of Transport Service Providers under Sustainable Urban Development

transport development based on the concept of "smart" city and municipal ecologistics» (State Registration Number 0117U003871).

\section{References}

0352.ua (2021). Oficcial site [Link]

Akbulaev, N. (2020). The impact of the taxi service mobile applications on the financial condition of taxi companies. International Journal of Scientific and Technology Research, 9(2), 2144-2150. [Google Scholar]

Borysova, T., \& Monastyrskyi, G. (2018). Marketing innovation activity of urban public transport: results of the empirical study. Marketing and Management of Innovations, 3, 229-240. [Google Scholar] [CrossRef]

Borysova, T., Monastyrskyi, G., Zielinska, A., \& Barczak, M. (2019). Innovation Activity Development of Urban Public Transport Service Providers: Multifactor Economic and Mathematical Model. Marketing and Management of Innovations, 4, 98-109. [Google Scholar] [CrossRef]

Brych, V., Manzhula, V., Borysiak, O., Liakhovych, G., Halysh, N., \& Tolubyak, V. (2020). Communication Model of Energy Service Market Participants in the Context of Cyclic Management City Infrastructure. In 2020 10th International Conference on Advanced Computer Information Technologies (ACIT) (pp. 678-681). IEEE. [Google Scholar] [CrossRef]

Brych, V., Mykytyuk, P., Halysh, N., Borysiak, O., Zhekalo, G., \& Sokol, M. (2021). Management Model of Energy Enterprises Innovative Development Within Physiological Working Conditions. Propósitos y Representaciones, 9(SPE3), 1173. [Google Scholar] [CrossRef]

Deschenes, A., Gaudreault, J., Rioux-Paradis, K., \& Redmont, C. (2020). Predicting Electric Vehicle Consumption: A Hybrid Physical-Empirical Model. World Electric Vehicle Journal, 11(1), 2. [Google Scholar]

European Commission. (2019). The European Green Deal. Retrieved from [Link]

European Union. (2020a). EU4Digital. Retrieved from [Link]

European Union. (2020b). European Neighbours South and East. Retrieved from [Link]

Grabovetsky, B. E. (2010). Methods of expert assessments: theory, methodology, areas of use. Vinnytsia: VNTU.

Granaturov, V. M., \& Shevchuk, O. B. (2000). Risks of entrepreneurial activity: problems of analysis. VM Granaturov, $O B$ Shevchuk-K.: Connectivity.

Guo, Z., Yu, B., Li, K., Yang, Y., Yao, B., \& Lin, Q. (2020). Locating battery supplying infrastructures for electric taxies. Transportation Letters, 12(2), 77-86. [Google Scholar] [CrossRef]

Hao, X., Wang, H., Lin, Z., \& Ouyang, M. (2020). Seasonal effects on electric vehicle energy consumption and driving range: A case study on personal, taxi, and ridesharing vehicles. Journal of Cleaner Production, 249, 119403. [Google Scholar] [CrossRef]

Kieu, L. M., Ou, Y., Truong, L. T., \& Cai, C. (2020). A class-specific soft voting framework for customer booking prediction in on-demand transport. Transportation Research Part C: Emerging Technologies, 114, 377-390. [Google Scholar] [CrossRef]

Kim, S., Chang, J. J. E., Park, H. H., Song, S. U., Cha, C. B., Kim, J. W., \& Kang, N. (2020). Autonomous taxi service design and user experience. International Journal of Human-Computer Interaction, 36(5), 429-448. [Google Scholar] [CrossRef]

Kuchakovs'ka, H. (2014). Models of creating a knowledge base of the expert system for choosing a specialty for entrants to higher education. Educational discourse, 2014, 1 (5), 129-138. [Google Scholar]

Liakhovych, G., Kupchak, V., Borysiak, O., Huhul, O., Halysh, N., Brych, V., \& Sokol, M. (2021). Innovative human capital management of energy enterprises and the role of shaping the environmental behavior of consumers of green energy based on the work of smart grids. Propósitos y Representaciones, 9(SPE3), 1293. [Google Scholar] [CrossRef]

Liang, X., de Almeida Correia, G. H., An, K., \& van Arem, B. (2020). Automated taxis' dial-a-ride problem with ride-sharing considering congestion-based dynamic travel times. Transportation Research Part C: Emerging Technologies, 112, 260-281. [Google Scholar] [CrossRef

Lokhandwala, M., \& Cai, H. (2020). Siting charging stations for electric vehicle adoption in shared autonomous fleets. Transportation Research Part D: Transport and Environment, 80, 102231. [Google Scholar] [CrossRef]

Nedosekin, A. O. (2004). Business risk assessment based on fuzzy data. St. Petersburg. Retrieved from [Link].

Nguyen-Phuoc, D. Q., Su, D. N., Tran, P. T. K., Le, D. T. T., \& Johnson, L. W. (2020). Factors influencing customer's loyalty towards ride-hailing taxi services-A case study of Vietnam. Transportation Research Part A: Policy and Practice, 134, 96-112. [Google Scholar] [CrossRef]

Shou, Z., Di, X., Ye, J., Zhu, H., Zhang, H., \& Hampshire, R. (2020). Optimal passenger-seeking policies on E-hailing platforms using Markov decision process and imitation learning. Transportation Research Part C: Emerging Technologies, 111, 91-113. [Google Scholar] [CrossRef]

SSSU. (2019). Energy balance of Ukraine. Retrieved from [Link]

TSNUA (2018). In Ukraine, the number of charging stations for electric vehicles has been calculated. Retrieved from [Link] UkrAvtoprom. (2021). Oficcial site. [Link]

Van Der Kam, M., Peters, A., Van Sark, W., \& Alkemade, F. (2019). Agent-based modelling of charging behaviour of electric vehicle drivers. JASSS, 22(4). [Google Scholar] [CrossRef] 
T., Borysova, G., Monastyrskyi, O., Borysiak, Yu., Protsyshyn. Priorities of Marketing, Competitiveness, and Innovative Development of Transport Service Providers under Sustainable Urban Development

Welch, T. F., Gehrke, S. R., \& Widita, A. (2020). Shared-use mobility competition: a trip-level analysis of taxi, bikeshare, and transit mode choice in Washington, DC. Transportmetrica A: transport science, 16(1), 43-55. [Google Scholar] [CrossRef]

Xie, P., Li, T., Liu, J., Du, S., Yang, X., \& Zhang, J. (2020). Urban flow prediction from spatiotemporal data using machine learning: A survey. Information Fusion, 59, 1-12. [Google Scholar] [CrossRef]

Zhou, Y., Wen, R., Wang, H., \& Cai, H. (2020). Optimal battery electric vehicles range: A study considering heterogeneous travel patterns, charging behaviors, and access to charging infrastructure. Energy, 197, 116945. [Google Scholar] [CrossRef]

Zhuang, W., Ye, J., Song, Z., Yin, G., \& Li, G. (2020). Comparison of semi-active hybrid battery system configurations for electric taxis application. Applied Energy, 259, 114171. [Google Scholar] [CrossRef]

Zielinska, A., \& Borysova, T. (2020). Research of the Level of Business Automation of the Taxi Service. Marketing and digital technologies: Collection of materials IV International Scientific practical conference September 24-25, 2020 / ONPU. Odessa: TES, 17-19. Retrieved from [Link]

Тетяна Борисова, д.е.н., професор, Західноукраїнський національний університет, Україна

Григорій Монастирський, д.е.н., професор, Західноукраїнський національний університет, Україна

Олена Борисяк, к.е.н., Західноукраїнський національний університет, Україна

Юлія Процишин, к.е.н., Західноукраїнський національний університет, Україна

Пріоритети маркетингової політики, підвищення конкурентоспроможності та інноваційного розвитку постачальників транспортних послуг у контексті сталого розвитку міста

Відстеження зростання ролі впровадження цілей сталого розвитку, з одного боку, а з іншого - використання програм Інтернету речей у різних сферах життя, зумовлюють транссормацію дизайну мислення людини щодо способу своєї мобільності. Актуальність розв'язання даної наукової проблеми полягає в необхідності перегляду муніципальної політики щодо підходів до використання відповідних видів громадського транспорту, удосконалення політики муніципальної транспортної інфраструктури через врахування тенденцій розвитку «зеленої» енергетики. У статті обгрунтовано потребу зосередження уваги на дослідженні зміни поведінки користувачів послуг таксі в Україні в умовах муніципальної екологістики, розвитку «зеленої» енергетики, розробки відповідних програм узгодження запитів користувачів і надавачів послуг таксі на засадах сталого розвитку міста та диджиталізації послуг таксі. Проаналізовано вплив сталого розвитку енергетики на диверсифікацію транспорту, рівень використання екологічних видів транспорту, зокрема електромобілів як таксі у залежності від кількості зарядних станцій, доступності до електроенергії. Методичним інструментарієм проведеного дослідження стали методи кластерного аналізу, експертного опитування, особистого інтерв'ю, статистичний аналіз та метод нечіткомножинного оцінювання. Об'єктом дослідження обрано служби таксі та користувачів послуг таксі Тернопільської області. Результати проведеного опитування засвідчили, що пріоритетними чинниками екологічної поведінки українських користувачів таксі $€$ рівень автоматизації бізнесу та величина автопарку служби таксі. За результатами валідного експертного опитування, проведеного з метою дослідження рівня екологічності транспортних засобів та рівня автоматизації бізнесу, встановлено, що більшість досліджуваних служб таксі характеризуються низьким рівнем екологічності. При цьому орієнтація на цілі сталого розвитку та екологічність має фрагментарний характер, а найбільш проблемними питаннями залишаються технічне забезпечення, наявність автоматизованої системи замовлень, велика частка зношення транспортних засобів у невеликих містах. Для визначення підходів до управління процесом екологізації, об'єкти дослідження упорядковано у порівняно однорідні групи. 3 цією метою здійснено кластерний аналіз, який дозволив згрупувати об'єкти дослідження у порівняно однорідні групи та обірунтувати доцільність розробки диференційованих стратегій, а також підтвердити думку про доцільність розробки різних підходів до розвитку екологічної складової залежно від рівня розвитку екологічності транспортних засобів, рівня автоматизації бізнесу та відносних часток автопарку. Результати проведеного дослідження можуть бути корисними для науковців та практиків у сфері інфрраструктури, менеджерів та власників служб таксі, представників місцевої виконавчої влади.

Ключові слова: сталий розвиток, маркетинг, автономна служба таксі, інновації, конкурентоспроможність, муніципальна екологістика, спільна мобільність, енергосервісні компанії, електроенергетика, відновлювальні джерела енергї̈, кластерний аналіз. 